\title{
'To see the Playes of Theatre newe wrought': Electronic Editions and Early Tudor Drama
}

Brett D. Hirsch

Early Theatre 16.2 (2013), 211-249

DOI: http://dx.doi.org/10.12745/et.16.2.13

This article considers the challenges and opportunities associated with electronic editions of early Tudor drama, as well as the new modes of scholarship enabled by their creation.

In early Tudor England the drama had sunk many fathoms below the level of the Miracle Plays ... The rise of the drama, under Elizabeth, is a kind of miracle, like the sculpture of Phidias appearing after the rude art of the artists who worked at Athens before the victories of Marathon and Salamis. ${ }^{1}$

The continued neglect of early Tudor drama suggests little has changed in the hundred years since Andrew Lang published this disparaging remark. A generation before, J.A. Symonds announced that the Tudor moralities 'can hardly be said to lie in the direct line of evolution between the Miracle and the legitimate Drama, but rather to be an abortive side-effort, which was destined to bear barren fruit. ${ }^{2}$ Routinely dismissed as 'thematically humanistic, theatrically dull, and aesthetically mediocre', ${ }^{3}$ early Tudor drama has, as Leah S. Marcus observes, typically 'interested scholars only as a transition to something else', ${ }^{4}$ namely, the drama of Shakespeare and his immediate contemporaries. Frederick S. Boas' Introduction to Tudor Drama, for example, begins with the acknowledgment that Shakespeare 'does not stand alone in isolated majesty', that

His work is the climax, the consummation of the efforts and achievements of forerunners for a century before he began to write. Unless we know something of what they were and did, of what they contributed to the English stage before Shakespeare came both to crown and to eclipse what they had so far accomplished, we shall not be able to see his own work in its true proportion and perspective. Some knowledge of predecessors and contemporaries in the field of

Brett D. Hirsch (brett.hirsch@uwa.edu.au) is an ARC Discovery Early Career Research Fellow and assistant professor of English and cultural studies at the University of Western Australia, as well as coordinating editor of Digital Renaissance Editions. 
drama is therefore necessary to every reader of Shakespeare after he has become more or less familiar with the plays preserved in the First Folio of 1623. This is alone a sufficient reason for the study of early Tudor drama. ${ }^{5}$

Thus dutiful scholars and students alike are reminded that 'however uninteresting in itself', the early Tudor drama 'is yet the necessary object of study for all who would trace the rise of the popular Elizabethan drama.. 6 The evolutionary paradigm of literary history reflected in these statements casts early Tudor drama either in the role of primordial soup, as the 'unpromising slime'7 from which the golden age of the Elizabethan and Jacobean commercial theatres emerged, or in the role of crude link between the crowning achievements of the medieval and Renaissance drama - a link that, however inconvenient, stubbornly refuses to go missing.

This is not to dismiss the importance of recent scholarly work on early Tudor drama, but to suggest that the drama associated with the commercial theatres of Shakespeare and his immediate contemporaries continues to dominate critical, editorial, pedagogical, and theatrical attention. As I have argued elsewhere, ${ }^{8}$ to address this imbalance in the canon of Renaissance drama as it is taught, studied, and performed requires not only the increased availability of responsibly edited texts of these neglected plays, but also the creation of open-access, media-rich, electronic editions of the same. The present paper extends this earlier and broader argument and considers the particular challenges and opportunities associated with electronic editions of early Tudor drama, as well as the new modes of scholarship enabled by their creation.

\section{True Proportions}

Early Tudor drama remains conspicuously underrepresented, if not absent entirely, from the handful of dedicated editorial series meeting the demand for critical editions of English drama in print. Since Clifford Leech inaugurated the series in 1958, The Revels Plays has published only two volumes of early Tudor drama, namely Ian Lancashire's edition of Two Tudor Interludes, containing modern-spelling texts of Youth and Hick Scorner, ${ }^{9}$ and Paula Neuss's edition of John Skelton's Magnificence, ${ }^{10}$ both published in 1980, both only printed in hardcover, and both now long out of print. The newer Revels Plays Companion Library series, launched in 1986, similarly offers only a single edition of early Tudor drama, namely, a modern-spelling text 
of Richard Edwards's Damon and Pythias in Ros King's 2001 edition of his works. ${ }^{11}$ Since both series appeal (or are marketed) to a smaller audience of textual scholars and area specialists, relatively low print runs (usually only in hardcover $)^{12}$ ensure that volumes are priced accordingly and reside for the most part in academic libraries, too expensive for classroom (or even personal) use. In the catalogues of the more affordable paperback series aimed at a wider student readership, including the Arden Early Modern Drama, New Mermaids, Norton Critical Editions, and Revels Student Editions series, only three volumes of early Tudor drama have been published, with a total of five different plays between them: G.A. Lester's Three Late Medieval Morality Plays for the New Mermaids (1981), which contains Everyman, Mankind, and Mundus et Infans; Charles Whitworth's Three Sixteenth Century Comedies, also for New Mermaids (1984), which contains Gammer Gurton's Needle and Ralph Roister Doister; and, Douglas Bruster and Eric Rasmussen's Arden Early Modern Drama edition of Everyman and Mankind (2009). ${ }^{13}$ The dutiful student and devoted scholar hungering for early Tudor drama beyond these five plays must, therefore, forage elsewhere for editorial sustenance.

In 2004, Alexandra F. Johnston lauded scholarly efforts since the midtwentieth century that resulted in 'the modern stage revival of many of the early plays both religious and secular', the 'gathering and editing of all the surviving written evidence for drama, music and ceremony' during the Tudor period, and 'the re-editing of all the surviving play texts'. ${ }^{14}$ Given the tremendous successes of the Records of Early English Drama and similar projects to reinvigorate modern scholarship and performance of Tudor drama to which she refers, Johnston may be forgiven for exaggerating the editorial treatment of these plays since the twentieth century. Some early Tudor drama remains available only in photo- or type-facsimile or diplomatic transcription, mostly produced in the first half of the twentieth century under the auspices of the Malone Society Reprints and the Tudor Facsimile Texts series. These include The Contention between Liberality and Prodigality, July and Julian, The Pedlar's Prophecy, Virtuous and Godly Susanna, and over half of the extant interlude fragments. The most surprising addition to this list is George Whetstone's Promos and Cassandra, a dramatic reworking of Cinthio's Hecatommithi, both long recognized as sources for the main plot of Shakespeare's Measure for Measure. A bibliographical tally of critical editions of the ninetytwo extant early Tudor plays and fragments in English - excluding closet and Latin plays - published since 1900 reveals that only seventy-six (or $82.60 \%$ ) of these have been edited, and that for many as fourteen plays (or 
15.21\%), only a single twentieth-century critical edition is available (Table 1). Out of the total ninety-two plays and fragments, thirteen are only available in modern-spelling editions and eleven only in old spelling. ${ }^{15}$

Table 1. Critical Editions of Early Tudor Drama in English, 1900-2013. For bibliographical details, see Appendix 1.

\begin{tabular}{crrrrrrr}
\hline $\begin{array}{c}\text { Date } \\
\text { Published }\end{array}$ & $\begin{array}{c}\text { Editions } \\
\text { by }\end{array}$ & $\begin{array}{c}\text { Total } \\
\text { Volume }\end{array}$ & $\begin{array}{c}\text { Percent } \\
\text { Total } \\
\text { Corpus }\end{array}$ & $\begin{array}{c}\text { Modern } \\
\text { Spelling }\end{array}$ & $\begin{array}{c}\text { Old } \\
\text { Spelling }\end{array}$ & $\begin{array}{c}\text { Ondy } \\
\text { Spelling }\end{array}$ & $\begin{array}{c}\text { Only Old } \\
\text { Spelling }\end{array}$ \\
\hline $1900-1909$ & 45 & 58 & 63.04 & 47 & 28 & 30 & 11 \\
$1910-1919$ & 11 & 19 & 20.65 & 6 & 15 & 4 & 13 \\
$1920-1929$ & 13 & 28 & 30.43 & 9 & 25 & 3 & 19 \\
$1930-1939$ & 15 & 18 & 19.56 & 11 & 8 & 10 & 5 \\
$1940-1949$ & 11 & 7 & 7.60 & 5 & 3 & 4 & 2 \\
$1950-1959$ & 8 & 6 & 6.52 & 3 & 3 & 3 & 3 \\
$1960-1969$ & 17 & 25 & 27.17 & 20 & 11 & 14 & 5 \\
$1970-1979$ & 22 & 34 & 36.95 & 20 & 22 & 12 & 14 \\
$1980-1989$ & 24 & 36 & 39.13 & 14 & 27 & 9 & 22 \\
$1990-1999$ & 13 & 24 & 26.08 & 7 & 19 & 5 & 17 \\
$2000-2009$ & 13 & 14 & 15.21 & 5 & 12 & 2 & 9 \\
$2010-2013$ & 3 & 12 & 13.04 & 12 & 0 & 12 & 0 \\
$1900-1989$ & 166 & 75 & 81.52 & 62 & 61 & 12 & 11 \\
$1990-2013$ & 29 & 35 & 38.04 & 18 & 25 & 10 & 17 \\
$1900-2013$ & 195 & 76 & 82.60 & 65 & 63 & 13 & 11 \\
\hline
\end{tabular}

Even if Johnston's assessment of the editorial landscape is somewhat generous, it is true that the majority of early Tudor drama was edited in some form during the twentieth century. Most plays appear in mixed anthologies, though D.S. Brewer published collections of the plays of John Bale, John Heywood, and Henry Medwall in their Tudor Interludes series. ${ }^{16}$ With few exceptions, these editions of early Tudor drama were published before 1990 and are now out of print, while titles still in print (or are available by print-on-demand) are expensive. For example, the 2012 Broadview Anthology of Medieval Drama, edited by Christina Fitzgerald and John T. Sebastian and containing modern-spelling texts of ten early Tudor plays, is a USD $\$ 64.95$ paperback volume. ${ }^{17}$ The next most recent collection, ${ }^{18}$ Greg Walker's Medieval Drama: An Anthology, ${ }^{19}$ published in 2000 and containing eleven early Tudor plays in old spelling, is listed as a USD \$75.95 
paperback print-on-demand title. ${ }^{20}$ Titles in the Tudor Interludes series, published between 1979 and 1991 in old spelling, remain available from the publisher directly, priced at GBP $£ 45.00$ or USD $\$ 80.00$ for most volumes. ${ }^{21}$ In contrast, David Bevington's Medieval Drama, containing ten early Tudor plays and published in 1975, remained out of print until Hackett Publishing secured the rights to reprint it in 2012, in cloth, for USD $\$ 60.00 .^{22}$

The relative expense and limited availability of editions of early Tudor drama reflects the economics of demand and supply. While critical editions enable scholarship, facilitate teaching, and provide the basis for performance, Eugene Giddens has noted that 'the market continues to be driven by students, not scholars', ${ }^{23}$ because the biggest demand for critical editions is for classroom use. Since, to cite Roland Barthes' aphorism, the canon is 'what gets taught', this demand-driven model for the production of critical editions can only function to sustain the existing canon of early English drama, a process characterized by Michael Leslie as 'increasingly sterile reiteration'. ${ }^{24}$ A disparity in market share and demand means that editions of canonical drama that of Shakespeare and the commercial Elizabethan and Jacobean theatres in particular - are more readily available (in both old and modern spelling) and affordable than those of other dramatists and periods. This greater affordability and availability, as Gary Taylor has observed, facilitates flexible teaching, whereas the unavailability of affordable editions 'makes it correspondingly difficult to teach other dramatists at all, let alone flexibly'. ${ }^{25}$

The job of expanding the canon of early English drama requires a new model for the production of critical editions, a model driven neither by demand nor subject to the restraints imposed by the institutions of print publishing. ${ }^{26}$ We cannot wait to respond to a demand for critical editions of early Tudor drama that may never come, but must be proactive in their creation regardless. This new model must also rely on innovative practices of openaccess digital publishing, such that the production of critical editions is supported and maintained by flexible institutional partnerships and collaborations, in which autonomy is not surrendered to the presses. Such a structure will ensure that even if our work is not immediately popular, it is nonetheless readily accessible, not 'too expensive to be purchased by individual scholars and students' and relegated to the status of 'library-only editions. ${ }^{27}$ While a number of editorial projects are pioneering the use of open-access digital publishing, ${ }^{28}$ the precise shape of this new model remains to be seen. 


\section{Humanism, Dullness, and Mediocrity}

It is hard to avoid the conclusion that the critical, pedagogical, and theatrical privileging of Shakespeare (and, to a lesser extent, a select group of his immediate contemporaries in the commercial theatres of Elizabethan and Jacobean London), coupled with a concomitant tendency to patronize the earlier and deprecate the later drama, is both a contributing factor to, and a reflection of, the (relatively limited) editorial attention that has been paid to these plays. While the evolutionary paradigm of literary history, as the dominant critical mode, is certainly an important factor, what are the other reasons for the continued editorial neglect of early Tudor drama?

Let us consider the litany of charges routinely levelled at the plays by critics; namely, that they are 'thematically humanistic, theatrically dull, and aesthetically mediocre. ${ }^{29}$ As Kent Cartwright has argued, much recent criticism on the Elizabethan and Jacobean commercial theatre has traditionally emphasized its indebtedness to the morality tradition 'as opposed to the influence of a more formal academic and humanist theatre'. ${ }^{30}$ This 'valorizing of morality drama', exemplified in important studies by David Bevington and Robert Weimann, 'has entailed not only the dismissal of humanist theatricality but also the devaluing of other medieval forms, such as the saints' plays, civic mystery plays, and folk drama. ${ }^{31}$ To dismiss early Tudor drama as 'thematically humanistic' is to betray a misunderstanding of humanist drama as 'something arid, literary, elitist, and rule-bound'. It is to deny that 'the excitement of the Tudor stage derives partly from a humanist dramaturgy that embroils feelings and emotions in the creation of meaning', and to perpetuate a 'binary model' that refuses to acknowledge 'Tudor drama's triumphant mingling, balancing, and negotiating of sources and interests', humanist and otherwise. ${ }^{32}$

The traditional charge of theatrical 'dullness' is one that, I suspect, was levelled against early Tudor drama by earlier critics who had only ever experienced the plays on the page, and not in performance. Since the successful staging of a condensed version of the York cycle for the Festival of Britain in 1951, and the abolishment of theatrical censorship in the United Kingdom in 1968 that had previously impeded the staging of early drama on account of its frequent impersonation of the deity, ${ }^{33}$ there has been a revival of interest in the performance of medieval and early Tudor drama in Britain and further abroad. This growth of interest coincides with the emergence of professional and amateur theatre groups dedicated to early drama in the 1960s and 1970s, 
such as the Medieval Players (founded ca 1970, disbanded ca 1990) and the Joculatores Lancastrienses (founded ca 1960), as well as the inauguration of scholarly associations to promote and study early drama in production, such as the Poculi Ludique Societas (founded ca 1964). ${ }^{34}$ The continued success of such performances and modern recreations, Glynne Wickham notes, has not only 'revealed how lively' early Tudor plays are on stage and 'how suitable as texts for practical class-work in small study groups', but also 'how relevant their conventions are to any genuine understanding of both late Elizabethan drama and theatre and modern street and arena theatre. 35

T.W. Craik has argued that early Tudor plays 'were far more effective when acted than we can guess when we merely read them' because 'so much of the meaning ... is conveyed by the significant use of action and costume' and 'that unless this is borne in the mind they cannot be appreciated or even properly understood'. ${ }^{36}$ For critics unable (or unwilling) to see or imagine early Tudor drama in performance, the dismissal of the plays as 'theatrically dull' and 'aesthetically mediocre' is therefore understandable if they are assessed solely as reading texts, as literature and poetry. Read in the unfair light of the crowning achievements of Middle English poetry or the later Elizabethan literature, the early Tudor plays, in contrast, have been found wanting by virtue of the 'relative poverty of their language'. ${ }^{37}$ Modern scholars and students unfamiliar with classical French theatre or conditioned on the blank verse of the later Elizabethan drama may also find the prosody of early Tudor drama variously crude, bombastic, or simply frustrating to read. The fourteener, while 'serious business in Tudor literature' and 'a weighty line for the first generation of Elizabethan writers and translators', 38 often, as T.S. Eliot observed, 'repels readers who have not the patience to accustom their ears and nerves to its beat'. ${ }^{39}$ However alienating these features of the early Tudor drama may be for the modern reader, they are rendered immediately accessible by performance.

\section{Bringing Early Tudor Drama Online}

Print remains the dominant medium for the publication of critical editions, not just of early English drama. The electronic medium, however, has much to commend itself as a viable alternative, if not as a successor. The type and amount of content that may be included in print editions are subject to commercial restrictions set by their publishers - such as word and page limits, print runs, format, etc. - as well as the technological limitations 
of the medium itself. Electronic editions, by contrast, can present multiple and interlinked versions of the same texts, alongside relevant sources, analogues, and adaptations, in both old and modern spelling, all with multiple levels of annotation and commentary. Rich multimedia content may also be incorporated, such that critical editions offer digitized facsimile images of the texts and relevant performance materials, audio recordings, and still and moving images. Unlike print editions, in which the contents are static and (literally) bound, electronic editions are able to facilitate dynamic interaction between its contents by and between its users through customization, annotation, discussion, and play. ${ }^{40}$

Many innate features of early Tudor drama suggest that electronic editions, rather than print, may better serve readers of the plays. Unlike plays prepared for the later commercial London theatres and their heterogeneous audiences, the impetus for the performance of early Tudor drama was typically 'some larger collective activity on the part of a household, parish, town, or other institution', and thus authors and audiences 'could count on a high degree of common knowledge and group cohesion'. ${ }^{41}$ As Leah S. Marcus has noted, this 'shared knowledge has to be recovered ... before we can fully appreciate the vitality and daring of the plays', and early Tudor drama 'invariably increases in interest the more we are able to immerse ourselves in its immediate political contexts. ${ }^{42}$

What a print edition can only describe in static words and images, an electronic edition can recreate with rich multimedia and dynamic content. Marcus's term is thus prescient: since early Tudor drama is so intimately tied to particular places, spaces, and local contexts, the electronic medium is the best way to 'immerse' the reader in the cultural, intellectual, and spatial environments of their original performances, albeit virtually. An electronic edition of John Redford's Wit and Science, for example, may incorporate audio recordings of choral performances of its songs in various musical settings, allowing the reader-as-listener to experience the songs in performance. ${ }^{43}$ Similarly, by integrating virtual reality software more commonly used in architecture, archaeology, and gaming, an electronic edition of Henry Medwall's Fulgens and Lucres, for example, may allow readers-as-directors to virtually block scenes of the play in an interactive three-dimensional scale model of the Great Hall in Lambeth Palace, where the play was likely first staged. ${ }^{44}$ An electronic edition, through animated or dynamic text, may also better convey the ambiguities, both editorial and theatrical, present in some early Tudor plays than can be accomplished in print. 'By reading the plays in 
modern editions that identify the allegorical persons by name before they speak', Marcus suggests, 'we receive a false sense of certainty about the relationship of concept to person that was probably far less readily available to early audiences. ${ }^{45}$ An electronic edition of John Skelton's Magnificence, to use Marcus's example, may animate the speech prefixes for Courtly Abusion and Pleasure so they dynamically interchange at given intervals, reflecting Magnificence's initial mistaking of one for the other and transferring this uncertainty to the reader. ${ }^{46}$

If, as T.W. Craik suggests, 'no plays - those of the "Shakespearian" period not excepted - more thoroughly exploit their theatrical setting' than the early Tudor drama, ${ }^{47}$ then no medium better capitalizes on the vitality of performance than the electronic. Through the incorporation of digital or digitized video recordings, electronic editions may offer the reader-asviewer the opportunity to see early Tudor drama in performance and, in so doing, actively reject the traditional perception of the plays as 'theatrically dull'. Richard Brome Online and Queen's Men Editions (with its companion Performing the Queen's Men site) have already successfully pioneered the use of video clips of staged readings and theatrical performances as editorial annotation and commentary to the plays. Other projects, like the Digital Renaissance Editions, have proposed editions that will include video footage of staged productions, in whole and in part. ${ }^{48}$ Through the incorporation of video and other multimedia, features of the early Tudor drama otherwise difficult for readers to appreciate may be rendered accessible by virtual performance.

\section{Old Texts and New Customs}

In New Custom (1573), the Prologue announces 'Al thinges be not soe as in sight they doe seeme', and through 'triall', 'good Instruction, and knowledge of right', we 'may learne, how grosly wee err / Taking one thinge for an other'. Though the polemics of the interlude seek to demonstrate that Protestantism's seemingly 'newe' customs are instead a return to the 'Primitiue' (ie, 'original') doctrines and that the authority claimed by Catholicism through 'antiquitie' is illusory and perverse, its broader provocation to sustained introspection, dialogue, and critical reassessment of received tradition resonates with the present discussion. Before the 'newe Custome' of the reformers enabled such questions to be raised, the Prologue suggests, 'no man was able then to proue them [Catholic doctrine] the contrarie. ${ }^{49}$ 
Scholarship on early Tudor drama awaits a similar reformation, to reassess traditional claims and subject the critical assumptions of previous generations to rigorous testing. As in New Custom, such a reformation requires access to the 'original' texts of the early Tudor drama in order to pierce through the 'stubberne Doctrine' of received criticism. The paucity of available critical editions of early Tudor drama continues to stymie any such attempts and, as indicated by the bibliographical survey above, a century of print publication has yet to provide access to the entire canon of plays and fragments.

Electronic texts of early Tudor drama are similarly limited in terms of the range of plays available, accuracy of transcription, and richness of textual encoding (used to provide machine-readable structure). The principal digital sources of such transcriptions, Chadwyck-Healey's Literature Online (LION) and the Early English Books Online Text Creation Partnership (EEBO-TCP), are 'magnificent but flawed', with critics identifying a growing catalogue of errors in transcription and encoding such that 'few of [their] transcriptions fully meet the scholarly standards one associates with decent diplomatic editions in the print world'.50 The LION text of New Custom, for example, regularizes the position of speech headings and stage directions, and normalizes blackletter and roman type. It fails to encode abbreviations or properly render either the accented characters indicating them (eg, the macron 'a' and 'o' in 'Ignorāce' and 'Edificatiō') or any of the capitulum marking the beginning of speeches, among other errors. There is no EEBO-TCP transcription of the play.

Without accurate machine-readable transcriptions, we cannot subject early Tudor drama to computer-aided quantitative analysis of the sort now routinely undertaken on Shakespearean texts to reveal latent authorial, bibliographical, linguistic, stylistic, and thematic features that are simply not visible by other means. ${ }^{51}$ Electronic editions therefore may not only provide readers with access to (and enriched experiences of) early Tudor drama, but the richly encoded texts and transcriptions upon which they rely may also enable new modes of computational scholarship - the 'newe Custome' required to systematically test traditional claims about the development of early Tudor drama and its position in literary history. ${ }^{52}$

\section{Coda: From Ignorāce to Edificatiō}

So long as early Tudor drama remains relegated to the critical, editorial, pedagogical, and theatrical peripheries, limited demand for critical editions 
of these plays will never justify their commercial production in print. Openaccess digital publishing may prove to be the only feasible alternative to this dominant, demand-driven production model, maintained by the centuries old institutions of print and functioning to sustain existing canons. While electronic editions face many challenges - institutional and technological, practical and theoretical - the capacity of the medium to extend beyond the constraints of print, to facilitate interaction and immersion, and to incorporate performance materials and rich multimedia content, makes it an ideal environment for the study and rehabilitation of early Tudor drama. ${ }^{53}$ More than this, the creation of accurately transcribed, richly encoded, machinereadable texts will enable scholars to scrutinize persistent critical assumptions about the early Tudor drama through computer-aided analysis of the plays. Such methods, already routinely applied to Shakespearean texts, will allow detailed exploration of early Tudor drama at the level of the type, word, line, phrase, speech, character, scene, act, play, author, auspices, genre, or period, whether in isolation or in relationship to others across the corpus. To paraphrase Jasper Heywood's Hercules Furens, electronic editions will allow us to 'see the playes' of the early Tudor period 'newe wrought'. ${ }^{54}$ 


\section{Appendix 1: Critical Editions of Early Tudor Drama in English Published since 1900}

This survey excludes closet plays in English as well as Latin plays from the period. Similarly excluded are facsimile editions, performance scripts, foreign-language translations, selections and excerpts, reprints, and unpublished theses and dissertations.

\begin{tabular}{|c|c|c|}
\hline \multirow[t]{2}{*}{ Play Title } & \multicolumn{2}{|c|}{ Critical Editions } \\
\hline & Modern Spelling & Old Spelling \\
\hline Albion Knight (fragment) & 1906e Farmer & - \\
\hline All for Money & $\begin{array}{l}1985 \text { Palermo Concolato } \\
1969 \text { Schell \& Shuchter }\end{array}$ & 1904 Vogel \\
\hline Appius and Virginia & $\begin{array}{l}1988 \text { Hedley } \\
\text { 1908a Farmer }\end{array}$ & 1972 Happé \\
\hline Calisto and Melebea & 1905c Farmer & $\begin{array}{l}1979 \text { Axton } \\
1908 \text { Allen }\end{array}$ \\
\hline Cambyses & $\begin{array}{l}2013 \text { Betteridge \& Walker } \\
1976 \text { Fraser \& Rabkin } \\
1974 \text { Craik } \\
1934 \text { Baskervill, Heltzel \& } \\
\text { Nethercot }\end{array}$ & $\begin{array}{l}1975 \text { Johnson } \\
1966 \text { Creeth } \\
1924 \text { Adams }\end{array}$ \\
\hline Christ's Burial & - & 1982 Baker, Murphy \& Hall \\
\hline Christ's Resurrection & - & 1982 Baker, Murphy \& Hall \\
\hline Clyomon and Clamydes & - & 1968 Littleton \\
\hline Common Conditions & 1908a Farmer & 1915 Tucker Brooke \\
\hline The Conflict of Conscience & 1969 Schell \& Shuchter & - \\
\hline $\begin{array}{l}\text { The Contention between Lib- } \\
\text { erality and Prodigality }\end{array}$ & - & - \\
\hline The Conversion of Saint Paul & $\begin{array}{l}1976 \text { Wickham } \\
1929 \text { Tickner \& Baldwin } \\
1926 \text { Tickner }\end{array}$ & $\begin{array}{l}1993 \text { Coldewey } \\
1982 \text { Baker, Murphy \& Hall } \\
1975 \text { Bevington } \\
1924 \text { Adams }\end{array}$ \\
\hline $\begin{array}{l}\text { Courage, Kindness, Cleanness } \\
\text { (fragment) }\end{array}$ & - & - \\
\hline The Cruel Debtor (fragment) & - & - \\
\hline Damon and Pythias & $\begin{array}{l}2013 \text { Betteridge \& Walker } \\
2001 \text { King } \\
1906 \text { c Farmer }\end{array}$ & $\begin{array}{l}1980 \text { White } \\
1924 \text { Adams }\end{array}$ \\
\hline$D, G, T$ (fragment) & - & - \\
\hline
\end{tabular}




\begin{tabular}{|c|c|c|}
\hline \multirow[t]{2}{*}{ Play Title (cont'd) } & \multicolumn{2}{|c|}{ Critical Editions (cont'd) } \\
\hline & Modern Spelling & Old Spelling \\
\hline The Disobedient Child & 1905b Farmer & - \\
\hline Enough is as Good as a Feast & $\begin{array}{l}1969 \text { Schell \& Shuchter } \\
1967 \text { Benbow }\end{array}$ & - \\
\hline Everyman & 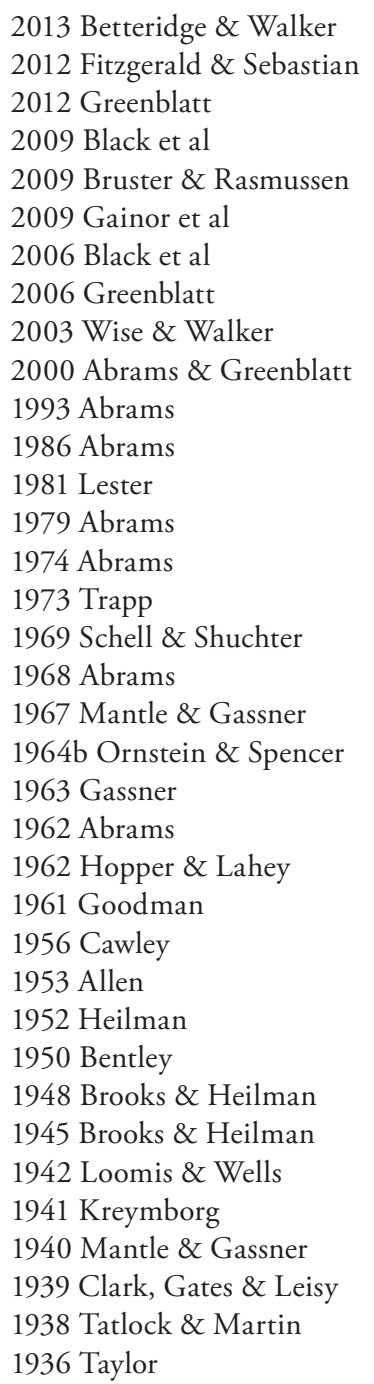 & $\begin{array}{l}2007 \text { Davidson, Walsh \& } \\
\text { Broos } \\
2000 \text { Walker } \\
1993 \text { Coldewey } \\
1985 \text { Gray } \\
1984 \text { Garbáty } \\
1980 \text { Cooper \& Wortham } \\
1975 \text { Bevington } \\
1970 \text { Robertson } \\
1961 \text { Cawley } \\
1947 \text { Woods, Watt \& } \\
\text { Anderson } \\
1941 \text { Woods, Watt \& } \\
\text { Anderson } \\
1924 \text { Adams } \\
1927 \text { Pollard } \\
1923 \text { Pollard } \\
1914 \text { Pollard } \\
1909 \text { Pollard } \\
1908 \text { Moses } \\
1904 \text { Pollard } \\
1903 \text { Moses }\end{array}$ \\
\hline
\end{tabular}


224 Issues in Review

\begin{tabular}{|c|c|c|}
\hline \multirow[t]{2}{*}{ Play Title (cont'd) } & \multicolumn{2}{|c|}{ Critical Editions (cont'd) } \\
\hline & Modern Spelling & Old Spelling \\
\hline Everyman (cont'd) & $\begin{array}{l}1935 \text { Mantle \& Gassner } \\
1935 \text { Parks \& Beatty } \\
1933 \text { Clark } \\
1931 \text { Hampden } \\
1929 \text { Moore } \\
1929 \text { Tickner \& Baldwin } \\
1928 \text { Schweikert } \\
1928 \text { Rubenstein } \\
1926 \text { Tickner } \\
\text { 1916 Tatlock \& Martin } \\
1910 \text { Child } \\
\text { 1909 Rhys } \\
\text { 1906h Farmer } \\
\text { 1902 Sidgwick }\end{array}$ & \\
\hline $\begin{array}{l}\text { The Four Cardinal Virtues } \\
\text { (fragment) }\end{array}$ & - & - \\
\hline $\begin{array}{l}\text { The (Nature of the) Four } \\
\text { Elements }\end{array}$ & 1905c Farmer & $\begin{array}{l}1979 \text { Axton } \\
1927 \text { Pollard } \\
1923 \text { Pollard } \\
1903 \text { Fischer }\end{array}$ \\
\hline The Four PP & $\begin{array}{l}1976 \text { Fraser \& Rabkin } \\
1968 \text { Hussey \& Agarwala } \\
1963 \text { Gassner } \\
1962 \text { Hopper \& Lahey } \\
1936 \text { Taylor } \\
1934 \text { Boas } \\
\text { 1906g Farmer } \\
\text { 1905a Farmer }\end{array}$ & $\begin{array}{l}2000 \text { Walker } \\
1991 \text { Axton \& Happé } \\
1937 \text { De la Bère } \\
1924 \text { Adams }\end{array}$ \\
\hline Fulgens and Lucres & $\begin{array}{l}2013 \text { Betteridge \& Walker } \\
2012 \text { Fitzgerald \& Sebastian } \\
2009 \text { Black et al } \\
1981 \text { Meredith } \\
1976 \text { Wickham } \\
1934 \text { Boas }\end{array}$ & $\begin{array}{l}2000 \text { Walker } \\
1981 \text { Moeslein } \\
1980 \text { Nelson } \\
1972 \text { Happé } \\
1966 \text { Creeth } \\
1926 \text { Boas \& Reed }\end{array}$ \\
\hline
\end{tabular}




\begin{tabular}{|c|c|c|}
\hline \multirow[t]{2}{*}{ Play Title (cont'd) } & \multicolumn{2}{|c|}{ Critical Editions (cont'd) } \\
\hline & Modern Spelling & Old Spelling \\
\hline Gammer Gurton's Needle & $\begin{array}{l}2013 \text { Betteridge \& Walker } \\
2012 \text { Fitzgerald \& Sebastian } \\
1997 \text { Whitworth } \\
1984 \text { Whitworth } \\
1976 \text { Fraser \& Rabkin } \\
1963 \text { Gassner } \\
1952 \text { Heilman } \\
\text { 1934 Baskervill, Heltzel \& } \\
\text { Nethercot } \\
\text { 1934 Boas } \\
\text { 1906a Farmer } \\
\text { 1906f Farmer }\end{array}$ & $\begin{array}{l}1984 \text { Tydeman } \\
1966 \text { Creeth } \\
1924 \text { Adams } \\
1920 \text { Brett-Smith } \\
1903 \text { Bradley }\end{array}$ \\
\hline Gentleness and Nobility & 1908b Farmer & $\begin{array}{l}1979 \text { Axton } \\
1941 \text { Cameron }\end{array}$ \\
\hline Gismond of Salerne & - & 1912 Cunliffe \\
\hline The Glass of Government & - & 1907 Cunliffe \\
\hline Godly Queen Hester & 1906e Farmer & $\begin{array}{l}2000 \text { Walker } \\
1904 \text { Greg }\end{array}$ \\
\hline God's Promises & $\begin{array}{l}1909 \text { Rhys } \\
\text { 1907a Farmer }\end{array}$ & $\begin{array}{l}\text { 1985-86 Happé } \\
\text { 1909 Jones }\end{array}$ \\
\hline $\begin{array}{l}\text { Good Order or Old Christ- } \\
\text { mas (fragment) }\end{array}$ & - & - \\
\hline Gorboduc & $\begin{array}{l}1992 \text { Tydeman } \\
1976 \text { Fraser \& Rabkin } \\
1974 \text { Craik } \\
1970 \text { Cauthen } \\
1963 \text { Gassner } \\
1938 \text { McIlwraith } \\
1936 \text { Taylor } \\
1934 \text { Baskervill, Heltzel \& } \\
\text { Nethercot } \\
1928 \text { Schweikert } \\
1910 \text { Thorndike } \\
1906 \text { c Farmer }\end{array}$ & $\begin{array}{l}1966 \text { Creeth } \\
1924 \text { Adams } \\
1912 \text { Cunliffe }\end{array}$ \\
\hline Hick Scorner & $\begin{array}{l}1980 \text { Lancashire } \\
1905 \text { c Farmer }\end{array}$ & - \\
\hline Horestes & - & 1982 Axton \\
\hline Impatient Poverty & $\begin{array}{l}1984 \text { Tennenhouse } \\
\text { 1907b Farmer }\end{array}$ & 1911 McKerrow \\
\hline
\end{tabular}


226 Issues in Review

Play Title (cont'd) Critical Editions (cont'd)

\begin{tabular}{|c|c|c|}
\hline & \multirow[b]{2}{*}{ Modern Spelling } & \multirow[b]{2}{*}{ Old Spelling } \\
\hline & & \\
\hline Jack Juggler & $\begin{array}{l}\text { 1968 Hussey \& Agarwala } \\
\text { 1906a Farmer }\end{array}$ & $\begin{array}{l}1984 \text { Tydeman } \\
1982 \text { Axton } \\
1914 \text { Williams }\end{array}$ \\
\hline Jacob and Esau & 1906e Farmer & 1992 White \\
\hline Jocasta & - & $\begin{array}{l}1912 \text { Cunliffe } \\
1907 \text { Cunliffe } \\
1906 \text { Cunliffe }\end{array}$ \\
\hline John Baptist's Preaching & 1907a Farmer & $\begin{array}{l}2000 \text { Walker } \\
\text { 1985-86 Happé }\end{array}$ \\
\hline John the Evangelist & 1907b Farmer & - \\
\hline Johan Johan the Husband & $\begin{array}{l}1972 \text { Denny } \\
1968 \text { Hussey \& Agarwala } \\
1962 \text { Hopper \& Lahey } \\
1942 \text { Loomis \& Wells } \\
1935 \text { Parks \& Beatty } \\
\text { 1928 Rubenstein } \\
\text { 1908a Farmer } \\
\text { 1908c Farmer } \\
\text { 1905a Farmer }\end{array}$ & $\begin{array}{l}1991 \text { Axton \& Happé } \\
1975 \text { Bevington } \\
1966 \text { Creeth } \\
1937 \text { De la Bère } \\
\text { 1924 Adams } \\
\text { 1903a Pollard }\end{array}$ \\
\hline July and Julian & - & - \\
\hline The Killing of the Children & - & $\begin{array}{l}1993 \text { Coldewey } \\
1982 \text { Baker, Murphy \& Hall }\end{array}$ \\
\hline King Darius & 1906a Farmer & - \\
\hline King Johan & $\begin{array}{l}1965 \text { Armstrong } \\
\text { 1907a Farmer }\end{array}$ & $\begin{array}{l}\text { 1985-86 Happé } \\
1979 \text { Happé } \\
1969 \text { Adams } \\
1966 \text { Creeth } \\
1927 \text { Pollard } \\
1923 \text { Pollard } \\
1914 \text { Pollard } \\
1909 \text { Pollard } \\
1904 \text { Pollard }\end{array}$ \\
\hline $\begin{array}{l}\text { The Life and Repentance of } \\
\text { Mary Magdalene }\end{array}$ & - & $\begin{array}{l}1992 \text { White } \\
1902 \text { Carpenter }\end{array}$ \\
\hline Like Will to Like & $\begin{array}{l}2012 \text { Fitzgerald \& Sebastian } \\
1974 \text { Somerset } \\
\text { 1906d Farmer }\end{array}$ & 1972 Happé \\
\hline $\begin{array}{l}\text { The Longer Thou Livest the } \\
\text { More Fool Thou Art }\end{array}$ & 1967 Benbow & 1900 Brandl \\
\hline
\end{tabular}




\begin{tabular}{|c|c|c|}
\hline \multirow[t]{2}{*}{ Play Title (cont'd) } & \multicolumn{2}{|c|}{ Critical Editions (cont'd) } \\
\hline & Modern Spelling & Old Spelling \\
\hline (The Play of) Love & $\begin{array}{l}1974 \text { Somerset } \\
1905 \text { a Farmer }\end{array}$ & $\begin{array}{l}\text { 1991 Axton \& Happé } \\
1979 \text { La Rosa } \\
1944 \text { Cameron } \\
1937 \text { De la Bère }\end{array}$ \\
\hline $\begin{array}{l}\text { Love Feigned and Unfeigned } \\
\text { (fragment) }\end{array}$ & - & - \\
\hline $\begin{array}{l}\text { Lucidus and Dubius } \\
\text { (fragment) }\end{array}$ & - & - \\
\hline $\begin{array}{l}\text { (The Play of) Lucrece } \\
\text { (fragment) }\end{array}$ & - & - \\
\hline Lusty Juventus & $\begin{array}{l}1974 \text { Somerset } \\
1905 \text { b Farmer }\end{array}$ & 1982 Thomas \\
\hline Magnificence & $\begin{array}{l}1980 \text { Neuss } \\
1959 \text { Henderson } \\
1948 \text { Henderson } \\
1931 \text { Henderson }\end{array}$ & $\begin{array}{l}2000 \text { Walker } \\
1979 \text { Happé } \\
1927 \text { Pollard } \\
1923 \text { Pollard } \\
1914 \text { Pollard } \\
1909 \text { Pollard } \\
1908 \text { Ramsay } \\
1904 \text { Pollard }\end{array}$ \\
\hline Mankind & $\begin{array}{l}2012 \text { Fitzgerald \& Sebastian } \\
2009 \text { Black et al } \\
2009 \text { Bruster \& Rasmussen } \\
2006 \text { Black et al } \\
1981 \text { Lester } \\
1976 \text { Wickham } \\
1974 \text { Somerset } \\
\text { 1907b Farmer }\end{array}$ & $\begin{array}{l}2008 \text { Ashley \& NeCastro } \\
2000 \text { Walker } \\
1995 \text { Knittel \& Fattic } \\
1993 \text { Coldewey } \\
1985 \text { Gray } \\
1975 \text { Bevington } \\
1969 \text { Eccles } \\
1924 \text { Adams } \\
1904 \text { Furnivall \& Pollard }\end{array}$ \\
\hline $\begin{array}{l}\text { The Marriage of Wit and } \\
\text { Science }\end{array}$ & 1908a Farmer & 1975 Lennam \\
\hline $\begin{array}{l}\text { The Marriage of Wit and } \\
\text { Wisdom }\end{array}$ & $\begin{array}{l}1976 \text { Wickham } \\
\text { 1908a Farmer }\end{array}$ & - \\
\hline
\end{tabular}


228 Issues in Review

Play Title (cont'd)

Critical Editions (cont'd)

\begin{tabular}{|c|c|c|}
\hline & Modern Spelling & Old Spelling \\
\hline Mary Magdalene & - & $\begin{array}{l}1993 \text { Coldewey } \\
1982 \text { Baker, Murphy \& Hall } \\
1975 \text { Bevington } \\
1927 \text { Pollard } \\
1924 \text { Adams } \\
1923 \text { Pollard } \\
1914 \text { Pollard } \\
1909 \text { Pollard } \\
1904 \text { Pollard }\end{array}$ \\
\hline Misogonus & $\begin{array}{l}1979 \text { Barber } \\
1906 \text { e Farmer }\end{array}$ & 1911 Bond \\
\hline Nature & 1907b Farmer & $\begin{array}{l}1981 \text { Moeslein } \\
1980 \text { Nelson }\end{array}$ \\
\hline New Custom & 1906a Farmer & - \\
\hline Nice Wanton & $\begin{array}{l}2012 \text { Fitzgerald \& Sebastian } \\
1984 \text { Tennenhouse } \\
1977 \text { Kruse } \\
1976 \text { Wickham } \\
\text { 1946 Clark } \\
\text { 1905b Farmer }\end{array}$ & - \\
\hline The Pardoner and the Friar & $\begin{array}{l}2005 \text { Kinney } \\
1968 \text { Hussey \& Agarwala } \\
1942 \text { Loomis \& Wells } \\
\text { 1906g Farmer } \\
\text { 1905a Farmer }\end{array}$ & $\begin{array}{l}1991 \text { Axton \& Happé } \\
1937 \text { De la Bère } \\
1927 \text { Pollard } \\
1923 \text { Pollard } \\
1914 \text { Pollard } \\
1909 \text { Pollard } \\
1904 \text { Pollard }\end{array}$ \\
\hline Patient and Meek Grissell & 1996 Gildenhuys & - \\
\hline The Pedlar's Prophecy & - & - \\
\hline The Prodigal Son (fragment) & - & - \\
\hline Promos and Cassandra & - & - \\
\hline
\end{tabular}




\begin{tabular}{|c|c|c|}
\hline \multirow[t]{2}{*}{ Play Title (cont'd) } & \multicolumn{2}{|c|}{ Critical Editions (cont'd) } \\
\hline & Modern Spelling & Old Spelling \\
\hline Ralph Roister Doister & $\begin{array}{l}\text { 1984 Whitworth } \\
1963 \text { Gassner } \\
1936 \text { Taylor } \\
1935 \text { Parks \& Beatty } \\
\text { 1934 Baskervill, Heltzel \& } \\
\text { Nethercot } \\
\text { 1934 Boas } \\
1928 \text { Schweikert } \\
1912 \text { Child } \\
1910 \text { Thorndike } \\
\text { 1907c Farmer } \\
\text { 1906b Farmer } \\
\text { 1901 Williams \& Robin }\end{array}$ & $\begin{array}{l}1984 \text { Tydeman } \\
1966 \text { Creeth } \\
1939 \text { Scheurweghs } \\
1924 \text { Adams } \\
1903 \text { Flügel }\end{array}$ \\
\hline Respublica & $\begin{array}{l}1969 \text { Schell \& Shuchter } \\
1907 \text { b Farmer }\end{array}$ & $\begin{array}{l}1952 \text { Greg } \\
1905 \text { Magnus }\end{array}$ \\
\hline $\begin{array}{l}\text { The Resurrection of Our Lord } \\
\text { (fragment) }\end{array}$ & - & - \\
\hline Robin Hood and the Friar & $\begin{array}{l}1978 \text { Parfitt } \\
1935 \text { Parks \& Beatty } \\
1928 \text { Schweikert } \\
1910 \text { Child }\end{array}$ & $\begin{array}{l}1997 \text { Knight \& Ohlgren } \\
1981 \text { Wiles } \\
1924 \text { Adams }\end{array}$ \\
\hline $\begin{array}{l}\text { Robin Hood and the Potter } \\
\text { (fragment) }\end{array}$ & $\begin{array}{l}1978 \text { Parfitt } \\
1929 \text { Tickner \& Baldwin } \\
1926 \text { Tickner } \\
1910 \text { Child }\end{array}$ & $\begin{array}{l}1997 \text { Knight \& Ohlgren } \\
1981 \text { Wiles }\end{array}$ \\
\hline $\begin{array}{l}\text { Robin Hood and the Sherriff } \\
\text { (fragment) }\end{array}$ & $\begin{array}{l}1978 \text { Parfitt } \\
1910 \text { Child }\end{array}$ & $\begin{array}{l}1997 \text { Knight \& Ohlgren } \\
1981 \text { Wiles } \\
1924 \text { Adams }\end{array}$ \\
\hline $\begin{array}{l}\text { (The Croxton Play of the) } \\
\text { Sacrament }\end{array}$ & 2012 Fitzgerald \& Sebastian & $\begin{array}{l}2000 \text { Walker } \\
1993 \text { Coldewey } \\
1975 \text { Bevington } \\
1970 \text { Davis } \\
1924 \text { Adams } \\
1909 \text { Waterhouse }\end{array}$ \\
\hline
\end{tabular}


230 Issues in Review

Play Title (cont'd) Critical Editions (cont'd)

\begin{tabular}{|c|c|c|}
\hline & \multirow[b]{2}{*}{ Modern Spelling } & \multirow[b]{2}{*}{ Old Spelling } \\
\hline & & \\
\hline A Satire of the Three Estates & 1998 Mace & $\begin{array}{l}2000 \text { Walker } \\
1989 \text { Lyall } \\
1979 \text { Happé } \\
\text { 1954 Kinsley } \\
\text { 1931-36 Hamer } \\
\text { 1928 Ritchie }\end{array}$ \\
\hline $\begin{array}{l}\text { Somebody and Others } \\
\text { (fragment) }\end{array}$ & - & $\begin{array}{l}1977 \text { Houle } \\
1931 \text { Greg }\end{array}$ \\
\hline Supposes & $\begin{array}{l}1999 \text { Beecher } \\
1976 \text { Fraser \& Rabkin } \\
\text { 1964a Ornstein \& Spencer } \\
\text { 1934 Baskervill, Heltzel \& } \\
\text { Nethercot } \\
\text { 1934 Boas }\end{array}$ & $\begin{array}{l}1957 \text { Bullough } \\
1924 \text { Adams } \\
1911 \text { Bond } \\
1907 \text { Cunliffe } \\
1906 \text { Cunliffe }\end{array}$ \\
\hline $\begin{array}{l}\text { Temperance and Humility } \\
\text { (fragment) }\end{array}$ & - & - \\
\hline The Temptation of Our Lord & $\begin{array}{l}1976 \text { Wickham } \\
\text { 1907a Farmer }\end{array}$ & $\begin{array}{l}\text { 1985-86 Happé } \\
1919 \text { Schwemmer }\end{array}$ \\
\hline Terence in English (Andria) & 1987 Twycross & - \\
\hline Thersites & 1905c Farmer & $\begin{array}{l}1982 \text { Axton } \\
1927 \text { Pollard } \\
1923 \text { Pollard } \\
1914 \text { Pollard } \\
1909 \text { Pollard } \\
1904 \text { Pollard }\end{array}$ \\
\hline Three Laws & 1907a Farmer & $\begin{array}{l}2000 \text { Walker } \\
\text { 1985-86 Happé }\end{array}$ \\
\hline The Tide Tarrieth No Man & 1969 Schell \& Shuchter & 1907 Rühl \\
\hline Tom Tiler and his Wife & $\begin{array}{l}\text { 1908a Farmer } \\
\text { 1908c Farmer } \\
\text { 1906e Farmer }\end{array}$ & 1900 Schelling \\
\hline The Trial of Treasure & 1906a Farmer & - \\
\hline Virtuous and Godly Susanna & - & - \\
\hline Wealth and Health & 1907b Farmer & $\begin{array}{l}1922 \text { Holthausen } \\
1908 \text { Holthausen }\end{array}$ \\
\hline
\end{tabular}




\begin{tabular}{|c|c|c|}
\hline \multirow[t]{2}{*}{ Play Title (cont'd) } & \multicolumn{2}{|c|}{ Critical Editions (cont'd) } \\
\hline & Modern Spelling & Old Spelling \\
\hline (Play of the) Weather & $\begin{array}{l}2012 \text { Fitzgerald \& Sebastian } \\
1968 \text { Hussey \& Agarwala } \\
\text { 1905a Farmer }\end{array}$ & $\begin{array}{l}2000 \text { Walker } \\
1991 \text { Axton \& Happé } \\
1987 \text { Robinson } \\
\text { 1975 Bevington } \\
\text { 1972 Happé } \\
\text { 1924 Adams } \\
\text { 1903b Pollard }\end{array}$ \\
\hline Wisdom, Who is Christ & $\begin{array}{l}1998 \text { Riggio } \\
1929 \text { Tickner \& Baldwin } \\
1926 \text { Tickner }\end{array}$ & $\begin{array}{l}2008 \text { Klausner } \\
2000 \text { Walker } \\
1998 \text { Riggio } \\
1993 \text { Coldewey } \\
1982 \text { Baker, Murphy \& Hall } \\
1969 \text { Eccles } \\
1904 \text { Furnivall \& Pollard }\end{array}$ \\
\hline (The Play of) Wit and Science & $\begin{array}{l}2012 \text { Fitzgerald \& Sebastian } \\
1969 \text { Schell \& Shuchter } \\
\text { 1907b Farmer }\end{array}$ & $\begin{array}{l}1975 \text { Bevington } \\
1972 \text { Happé } \\
1924 \text { Adams }\end{array}$ \\
\hline Witty and Witless & 1905a Farmer & $\begin{array}{l}1991 \text { Axton \& Happé } \\
1937 \text { De la Bère }\end{array}$ \\
\hline $\begin{array}{l}\text { The World and the Child } \\
\text { (Mundus et Infans) }\end{array}$ & $\begin{array}{l}1981 \text { Lester } \\
1969 \text { Schell \& Shuchter } \\
1931 \text { Hampden } \\
\text { 1905c Farmer }\end{array}$ & 1999 Davidson \& Happé \\
\hline (The Interlude of) Youth & $\begin{array}{l}2012 \text { Fitzgerald \& Sebastian } \\
1980 \text { Lancashire } \\
1969 \text { Schell \& Shuchter } \\
1931 \text { Hampden } \\
1922 \text { Gowans } \\
\text { 1906e Farmer }\end{array}$ & $\begin{array}{l}1972 \text { Happé } \\
1905 \text { Bang \& McKerrow }\end{array}$ \\
\hline
\end{tabular}

\section{Chronological List of Editions Cited}

[1900 Brandl] Alois Brandl (ed.), 'The Longer Thou Livest the More Fool Thou Art: Ein Drama aus der ersten Regierungsjahren der Königin Elisabeth', Jahrbuch der deutschen Shakespeare-Gesellschaft [Shakespeare Jahrbuch], 36 (1900), 14-60.

[1900 Schelling] Felix E. Schelling (ed.), 'Tom Tyler and His Wife', PMLA, 15.3 (1900), 253-89. 
232 Issues in Review

[1901 Williams \& Robin] W.H. Williams and P. A. Robin (eds), Ralph Roister Doister, Temple Dramatists (London, 1901).

[1902 Carpenter] Frederic Ives Carpenter (ed.), The Life and Repentaunce of Marie Magdalene by Lewis Wager (Chicago, 1902).

[1902 Sidgwick] Frank Sidgwick (ed.), Everyman, 2nd ed (London, 1902).

[1903 Bradley] Henry Bradley (ed.), Gammer Gurtons Nedle, in Charles Mills Gayley (gen. ed.), Representative English Comedies, vol. 1, From the Beginnings to Shakespeare (New York, 1903).

[1903 Fischer] Julius Fischer (ed.), Das 'Interlude of the Four Elements', Marburger Studien zur Englischen Philologie (Marburg, 1903).

[1903 Flügel] Ewald Flügel (ed.), Roister Doister, in Charles Mills Gayley (gen. ed.), Representative English Comedies, vol. 1, From the Beginnings to Shakespeare (New York, 1903).

[1903 Moses] Montrose J. Moses (ed.), Everyman (New York, 1903).

[1903a Pollard] Alfred W. Pollard (ed.), Mery Play betweene Johan Johan, Tyb, etc., in Charles Mills Gayley (gen. ed.), Representative English Comedies, vol. 1, From the Beginnings to Shakespeare (New York, 1903).

[1903b Pollard] Alfred W. Pollard (ed.), Play of the Wether, in Charles Mills Gayley (gen. ed.), Representative English Comedies, vol. 1, From the Beginnings to Shakespeare (New York, 1903).

[1904 Furnivall \& Pollard] F.J. Furnivall and Alfred W. Pollard (eds), The Macro Plays (London, 1904).

[1904 Greg] W.W. Greg (ed.), A New Enterlude of Godly Queene Hester, Edited from the Quarto of 1561, Materialien zur Kunde des üalteren Englischen Dramas (Louvain, 1904).

[1904 Pollard] Alfred W. Pollard (ed.), English Miracle Plays, Moralities, and Interludes, 4th rev. ed (Oxford, 1904).

[1904 Vogel] Ernst Vogel (ed.), 'All for Money. Ein Moralspiel aus der Zeit Shakespeares,' Jahrbuch der deutschen Shakespeare-Gesellschaft [Shakespeare Jahrbuch], 40 (1904), 129-86.

[1905 Bang \& McKerrow] W. Bang and R.B. McKerrow (eds), The Enterlude of Youth, nebst Fragmenten des Playe of Lucres und von Nature, Materialien zur Kunde des üalteren Englischen Dramas (Louvain, 1905).

[1905a Farmer] John S. Farmer (ed.), The Dramatic Writings of John Heywood (London, 1905). 
[1905b Farmer] John S. Farmer (ed.), The Dramatic Writings of Richard Wever and Thomas Ingelend (London, 1905).

[1905c Farmer] John S. Farmer (ed.), Six Anonymous Plays, First Series (London, 1905).

[1905 Magnus] Leonard A. Magnus (ed.), Respublica (London, 1905).

[1906 Cunliffe] John W. Cunliffe (ed.), Supposes and Jocasta (Boston, 1906).

[1906a Farmer] John S. Farmer (ed.), Anonymous Plays, Third Series (London, 1906).

[1906b Farmer] John S. Farmer (ed.), The Dramatic Writings of Nicholas Udall (London, 1906).

[1906c Farmer] John S. Farmer (ed.), The Dramatic Writings of Richard Edwards, Thomas Norton, and Thomas Sackville (London, 1906).

[1906d Farmer] John S. Farmer (ed.), The Dramatic Writings of Ulpian Fulwell (London, 1906).

[1906e Farmer] John S. Farmer (ed.), Six Anonymous Plays, Second Series (London, 1906).

[1906f Farmer] John S. Farmer (ed.), Gammer Gurton's Needle (London, 1906).

[1906g Farmer] John S. Farmer (ed.), The Pardoner and the Friar, The Curate and Neighbour Pratt (c. 1540), The Four P.P. (London, 1906).

[1906h Farmer] John S. Farmer (ed.), The Summoning of Everyman (London, 1906).

[1907 Cunliffe] John W. Cunliffe (ed.), The Complete Works of George Gascoigne, 2 vols (Cambridge, 1907).

[1907a Farmer] John S. Farmer (ed.), The Dramatic Writings of John Bale (London, 1907).

[1907b Farmer] John S. Farmer (ed.), Recently Recovered 'Lost' Tudor Plays, with Some Others (London, 1907).

[1907c Farmer] John S. Farmer (ed.), Ralph Roister Doister (London, 1907).

[1907 Rühl] Ernst Rühl (ed.), 'The Tide Taryeth No Man. Ein Moralspiel aus Shakespeares Jugendzeit', Jahrbuch der deutschen ShakespeareGesellschaft [Shakespeare Jahrbuch], 43 (1907), 1-52.

[1908 Allen] H. Warner Allen (ed.), Celestina (London, 1908). 
[1908a Farmer] John S. Farmer (ed.), Five Anonymous Plays, Fourth Series (London, 1908).

[1908b Farmer] John S. Farmer (ed.), The Spider and the Fly, Together with an Attributed Interlude entitled Gentleness and Nobility by John Heywood (London, 1608).

[1908c Farmer] John S. Farmer (ed.), Two Tudor 'Shrew' Plays (London, 1908).

[1908 Holthausen] Ferdinand Holthausen (ed.), 'An Enterlude of Welth and Helth', eine englische Moralität des XVI. Jahrhunderts (Kiel, 1908).

[1908 Moses] Montrose J. Moses (ed.), Everyman, rev. ed (New York, 1908).

[1908 Ramsay] Robert Lee Ramsay (ed.), Magnyfycence: A Moral Play (London, 1908).

[1909 Jones] Enrys Edward Jones (ed.), A Tragedye or enterlude manifestyng the chefe promyses of God vnto man (Erlangen, 1909).

[1909 Pollard] Alfred W. Pollard (ed.), English Miracle Plays, Moralities, and Interludes, 5th rev. ed. (Oxford, 1909).

[1909 Rhys] Ernest Rhys (ed.), Everyman with Other Interludes (London, 1909).

[1909 Waterhouse] Osborn Waterhouse (ed.), The Non-Cycle Mystery Plays, Together with the Croxton Play of the Sacrament (London, 1909).

[1910 Child] Clarence Griffin Child (ed.), The Second Shepherds' Play, Everyman, and Other Early Plays, The Riverside Literature Series (Boston, 1910).

[1910 Thorndike] Ashley Horace Thorndike (ed.), The Minor Elizabethan Drama, 2 vols (London, 1910).

[1911 Bond] R. Warwick Bond (ed.), Early Plays from the Italian (Oxford, 1911).

[1911 McKerrow] R.B. McKerrow (ed.), A Newe Interlude of Impacyente Pouerte from the Quarto of 1560, Materialien zur Kunde des älteren englischen Dramas (Louvain, 1911).

[1912 Child] Clarence Griffin Child (ed.), Ralph Roister Doister, The Riverside Literature Series (Boston, 1912).

[1912 Cunliffe] John W. Cunliffe (ed.), Early English Classical Tragedies (Oxford, 1912). 
[1914 Pollard] Alfred W. Pollard (ed.), English Miracle Plays, Moralities, and Interludes, 6th rev. ed. (Oxford, 1914).

[1914 Williams] W.H. Williams (ed.), Jacke Jugeler (Cambridge, 1914).

[1915 Tucker Brooke] C.F. Tucker Brooke (ed.), Common Conditions, Elizabethan Club Reprints (New Haven, 1915).

[1916 Tatlock \& Martin] John S.P. Tatlock and Robert G. Martin (eds), Representative English Plays (New York, 1916).

[1919 Schwemmer] Paul Schwemmer (ed.), John Bales drama: A brefe comedy or enterlude concernynge the temptacyon of Our Lorde (Nürnberg, 1919).

[1920 Brett-Smith] H.F.B. Brett-Smith (ed.), Gammer Gvrtons Nedle, The Percy Reprints (Oxford, 1920).

[1922 Gowans] Adam Luke Gowans (ed.), The Interlude of Youth, Reprinted in Modern English (London \& Glasgow, 1922).

[1922 Holthausen] Ferdinand Holthausen (ed.), An Enterlude of Welth and Helth, rev. ed. (Heidelberg, 1922).

[1923 Pollard] Alfred W. Pollard (ed.), English Miracle Plays, Moralities, and Interludes, 7th rev. ed. (Oxford, 1923).

[1924 Adams] Joseph Quincy Adams (ed.), Chief Pre-Shakespearean Dramas (Boston, 1924).

[1926 Boas \& Reed] F.S. Boas and A.W. Reed (eds), Fulgens \& Lucres: A Fifteenth-Century Secular Play, Tudor and Stuart Library (Oxford, 1926).

[1926 Tickner] F.J. Tickner (ed.), Earlier English Drama from Robin Hood to Everyman (London \& Edinburgh, 1926).

[1927 Pollard] Alfred W. Pollard (ed.), English Miracle Plays, Moralities, and Interludes, 8th rev. ed. (Oxford, 1927).

[1928 Ritchie] W. Tod Ritchie (ed.), The Bannatyne Manuscript, vol 2 (Edinburgh, 1928).

[1928 Rubenstein] H.F. Rubenstein (ed.), Great English Plays (New York \& London, 1928).

[1928 Schweikert] H.C. Schweikert (ed.), Early English Plays (New York, 1928). 
236 Issues in Review

[1929 Moore] John Robert Moore (ed.), Representative English Dramas (Boston, 1929).

[1929 Tickner \& Baldwin] F.J. Tickner and T.W. Baldwin (eds), Earlier English Drama from Robin Hood to Everyman, rev. ed. (New York, 1929).

[1931 Greg] W.W. Greg (ed.), Malone Society Collections 2:3, Malone Society Reprints (Oxford, 1931).

[1931 Hampden] John Hampden (ed.), Everyman. The Interlude of Youth. The World and the Child (London, 1931).

[1931 Henderson] Philip Henderson (ed.), The Complete Poems of John Skelton, Laureate (London, 1931).

[1931-36 Hamer] Douglas Hamer (ed.), The Works of Sir David Lindsay of the Mount, 1490-1555, 4 vols (Edinburgh, 1931-36).

[1933 Clark] Barrett H. Clark (ed.), World Drama, 2 vols (New York \& London, 1933).

[1934 Baskervill, Heltzel \& Nethercot] Charles Reed Baskervill, Virgil B. Heltzel, and Arthur H. Nethercot (eds), Elizabethan and Stuart Plays (New York, 1934).

[1934 Boas] F.S. Boas (ed.), Five Pre-Shakespearean Comedies, Oxford World's Classics (Oxford, 1934).

[1935 Mantle \& Gassner] Burns Mantle and John Gassner (eds), A Treasury of Theatre, 2nd ed. (New York, 1935).

[1935 Parks \& Beatty] Edd Winfield Parks and Richmod Croom Beatty (eds), The English Drama: An Anthology, 900-1642 (New York, 1935).

[1936 Taylor] Joseph Richard Taylor (ed.), European and Asiatic Plays: From Euripides to Shirley, 431 b.c. to 1642 a.d., Copley Drama Series (Boston, 1936).

[1937 De la Bère] Rupert De La Bère. John Heywood, Entertainer (London, 1937).

[1938 McIlwraith] A.K. McIlwraith (ed.), Five Elizabethan Tragedies, Oxford World's Classics (Oxford, 1938).

[1938 Tatlock \& Martin] John S.P. Tatlock and Robert G. Martin (eds), Representative English Plays, 2nd ed. (New York, 1938). 
[1939 Clark, Gates \& Leisy] David Lee Clark, William Bryan Gates, and Ernest Leisy (eds), The Voices of England and America, 2 vols (New York, 1939).

[1939 Scheurweghs] Gustave Scheurweghs (ed.), Nicholas Udall's Roister Doister, Materialien zur Kunde des älteren englischen Dramas (Louvain, 1939).

[1940 Mantle \& Gassner] Burns Mantle and John Gassner (eds), A Treasury of Theatre, 2nd ed. (New York, 1940).

[1941 Cameron] Kenneth Walter Cameron, Authorship and Sources of 'Gentleness and Nobility' (Raleigh, 1941).

[1941 Kreymborg] Alfred Kreymbord (ed.), Poetic Drama: An Anthology of Plays in Verse from the Ancient Greek to the Modern American (New York, 1941).

[1941 Woods, Watt \& Anderson] George B. Woods, Homer A. Watt, and George K. Anderson (eds), The Literature of England, 2nd ed., 2 vols (New York, 1941).

[1942 Loomis \& Wells] Roger Sherman Loomis and Henry W. Wells (eds), Representative Medieval and Tudor Plays (New York, 1942).

[1944 Cameron] Kenneth Walter Cameron (ed.), The Play of Love (Raleigh, 1944).

[1945 Brooks \& Heilman] Cleanth Brooks and Robert B. Heilman (eds), Understanding Drama: Eight Plays (New York, 1945).

[1946 Clark] William Smith Clark (ed.), Chief Patterns of World Drama (Boston, 1946).

[1947 Woods, Watt \& Anderson] George B. Woods, Homer A. Watt, and George K. Anderson (eds), The Literature of England, 3rd ed., 2 vols (New York, 1947).

[1948 Brooks \& Heilman] Cleanth Brooks and Robert B. Heilman (eds), Understanding Drama: Twelve Plays (New York, 1948).

[1948 Henderson] Philip Henderson (ed.), The Complete Poems of John Skelton, Laureate 2nd ed. (London, 1948).

[1950 Bentley] G.E. Bentley (ed.), The Development of English Drama: An Anthology (New York, 1950).

[1952 Heilman] Robert B. Heilman (ed.), An Anthology of English Drama before Shakespeare, Rinehart Editions (New York, 1952). 
238 Issues in Review

[1952 Greg] W.W. Greg (ed.), Respublica (Oxford, 1952).

[1953 Allen] John Piers Allen (ed.), Three Medieval Plays, The Drama Library (London, 1953).

[1954 Kinsley] James Kinsley (ed.), Ane Satyre of the Thrie Estaits (London, 1954).

[1956 Cawley] A.C. Cawley (ed.), Everyman and Medieval Miracle Plays (London, 1956).

[1957 Bullough] Geoffrey Bullough (ed.), Narrative and Dramatic Sources of Shakespeare, vol 1 (London, 1957).

[1959 Henderson] Philip Henderson (ed.), The Complete Poems of John Skelton, Laureate, 3rd ed. (London, 1959).

[1961 Cawley] A.C. Cawley (ed.), Everyman, Old and Middle English Texts (Manchester, 1961).

[1961 Goodman] Randolph G. Goodman (ed.), Drama on Stage (New York, 1961).

[1962 Abrams] M. Howard Abrams (gen. ed.), The Norton Anthology of English Literature, 2 vols (New York, 1962).

[1962 Hopper \& Lahey] Vincent F. Hopper and Gerald B. Lahey (eds), Medieval Mystery Plays, Morality Plays and Interludes, Theatre Classics for the Modern Reader (Woodbury, 1962).

[1963 Gassner] John Gassner (ed.), Medieval and Tudor Drama, Bantam Classics (New York, 1963).

[1964a Ornstein \& Spencer] Robert Ornstein and Hazelton Spencer (eds), Elizabethan and Jacobean Comedy: An Anthology (Boston, 1964).

[1964b Ornstein \& Spencer] Robert Ornstein and Hazelton Spencer (eds), Elizabethan and Jacobean Tragedy: An Anthology (Boston, 1964).

[1965 Armstrong] William A. Armstrong (ed.), Elizabethan History Plays, Oxford World's Classics (Oxford, 1965).

[1966 Creeth] Edmund Creeth (ed.), Tudor Plays: An Anthology of Early English Drama (Garden City, 1966).

[1967 Benbow] R. Mark Benbow (ed.), The Longer Thou Livest and Enough is as Good as a Feast, Regents Renaissance Drama (Lincoln, 1967). 
[1967 Mantle \& Gassner] Burns Mantle and John Gassner (eds), A Treasury of Theatre, 3rd ed. (New York, 1967).

[1968 Abrams] M. Howard Abrams (gen. ed.), The Norton Anthology of English Literature, 2nd ed., 2 vols (New York, 1968).

[1968 Hussey \& Agarwala] Maurice Hussey and Surendra Agarwala (eds), The Play of the Weather, and Other Tudor Comedies (New York, 1968).

[1968 Littleton] Betty J. Littleon (ed.), Clyomon and Clamydes, Studies in English Literature (Paris, 1968).

[1969 Adams] Barry B. Adams (ed.), King Johan (San Marino, 1969).

[1969 Eccles] Mark Eccles (ed.), The Macro Plays: The Castle of Perseverance, Wisdom, Mankind (London, 1969).

[1969 Schell \& Shuchter] Edgar T. Schell and J.D. Shuchter (eds), English Morality Plays and Moral Interludes, Rinehart Editions (New York, 1969).

[1970 Cauthen] Irby B. Cauthen (ed.), Gorbodux; or, Ferrex and Porrex, Regents Renaissance Drama (Lincoln, 1970).

[1970 Davis] Norman Davis (ed.), Non-Cycle Plays and Fragments (London, 1970).

[1970 Robertson] D.W. Robertson (ed.), The Literature of Medieval England (New York, 1970).

[1972 Denny] Neville Denny (ed.), Medieval Interludes (London, 1972).

[1972 Happé] Peter Happé (ed.), Tudor Interludes, Penguin Classics (Harmondsworth, 1972).

[1973 Trapp] J.B. Trapp (ed.), Medieval English Literature, Oxford Anthology of English Literature (Oxford, 1973).

[1974 Abrams] M. Howard Abrams (gen. ed.), The Norton Anthology of English Literature, 3rd ed., 2 vols (New York, 1974).

[1974 Craik] T.W. Craik (ed.), Minor Elizabethan Tragedies (London, 1974).

[1974 Somerset] J.A.B. Somerset (ed.), Four Tudor Interludes, Athlone Renaissance Library (London, 1974).

[1975 Bevington] David Bevington (ed.), Medieval Drama (Boston, 1975). 
[1975 Johnson] Robert Carl Johnson (ed.), A Critical Edition of Thomas Preston's Cambises, Salzburg Studies in English Literature (Salzburg, 1975).

[1975 Lennam] Trevor N.S. Lennam. Sebastian Westcott, the Children of Paul's, and The Marriage of Wit and Science (Toronto, 1975).

[1976 Fraser \& Rabkin] Russell A. Fraser and Norman Rabkin (eds), Drama of the English Renaissance, 2 vols (New York, 1976).

[1976 Wickham] Glynne Wickham (ed.), English Moral Interludes (London, 1976).

[1977 Houle] Peter J. Houle, 'A Reconstruction of the English Morality Fragment Somebody and Others', Papers of the Bibliographical Society of America, 71 (1977), 259-77.

[1977 Kruse] Axel Kruse (ed.), A Pretty Interlude called Nice Wanton, Sydney English Texts (Sydney, 1977).

[1978 Parfitt] George Parfitt, 'Early Robin Hood Plays: Two Fragments and a Bibliography', Renaissance \& Modern Studies, 22 (1978), 5-12.

[1979 Abrams] M. Howard Abrams (gen. ed.), The Norton Anthology of English Literature, 4th ed., 2 vols (New York, 1979).

[1979 Axton] Richard Axton (ed.), Three Rastell Plays, Tudor Interludes (Cambridge, 1979).

[1979 Barber] Lester E. Barber (ed.), Misogonus, Renaissance Drama (New York, 1979).

[1979 Happé] Peter Happé (ed.), Four Morality Plays, Penguin Classics (Harmondsworth, 1979).

[1979 LaRosa] Frank E. La Rosa (ed.), A Critical Edition of John Heywood's A Play of Love, Renaissance Drama (New York, 1979).

[1980 Cooper \& Wortham] Geoffrey Cooper and Christopher Wortham (eds), The Summoning of Everyman (Nedlands, 1980).

[1980 Lancashire] Ian Lancashire (ed.), Two Tudor Interludes, The Revels Plays (Manchester, 1980).

[1980 Nelson] Alan H. Nelson (ed.), The Plays of Henry Medwall, Tudor Interludes (Cambridge, 1980).

[1980 Neuss] Paula Neuss (ed.), Magnificence, The Revels Plays (Manchester, 1980). 
[1980 White] Jerry D. White (ed.), Richard Edwards' Damon and Pithias: A Critical Old-Spelling Edition, Renaissance Drama (New York, 1980).

[1981 Lester] G.A. Lester (ed.), Three Late Medieval Morality Plays, The New Mermaids (London, 1981).

[1981 Meredith] Peter Meredith (ed.), Fulgens \& Lucres, Leeds Studies in English (Leeds, 1981).

[1981 Moeslein] M.E. Moeslein (ed.), The Plays of Henry Medwall: A Critical Edition, Renaissance Drama (New York, 1981).

[1981 Wiles] David Wiles (ed.), The Early Plays of Robin Hood (Cambridge, 1981).

[1982 Axton] Marie Axton (ed.), Three Tudor Classical Interludes, Tudor Interludes (Cambridge, 1982).

[1982 Baker, Murphy \& Hall] Donald C. Baker, John L. Murphy, and Louis B. Hall (eds), The Late Medieval Religious Plays of Bodleian MSs Digby 133 and e Museo 160 (Oxford, 1982).

[1982 Thomas] Helen Scrborough Thomas (ed.), An Enterlude called Lusty Iuuentus, The Renaissance Imagination (New York, 1982).

[1984 Garbáty] Thomas J. Garbáty (ed.), Medieval English Literature (Lexington, 1984).

[1984 Tennenhouse] Leonard Tennenhouse (ed.), The Tudor Interludes: Nice Wanton and Impatient Poverty, The Renaissance Imagination (New York, 1984).

[1984 Tydeman] William Tydeman (ed.), Four Tudor Comedies, Penguin Classics (Harmondsworth, 1984).

[1984 Whitworth] Charles Walters Whitworth (ed.), Three Sixteenth-Century Comedies, The New Mermaids (London, 1984).

[1985 Gray] Douglas Gray (ed.), The Oxford Book of Late Medieval Verse and Prose (Oxford, 1985).

[1985 Palermo Concolato] Maria Grazia Palermo Concolato (ed.), All for Money, Strumenti (Napoli, 1985).

[1985-86 Happé] Peter Happé (ed.), The Complete Plays of John Bale, Tudor Interludes (Cambridge, 1985-86). 
[1986 Abrams] M. Howard Abrams (gen. ed.), The Norton Anthology of English Literature, 5th ed., 2 vols (New York, 1986).

[1987 Robinson] Vicki Knudsen Robinson (ed.), A Critical Edition of The Play of the Wether by John Heywood, The Renaissance Imagination (New York, 1987).

[1987 Twycross] Meg Twycross (ed.), Terence in England: An Early SixteenthCentury Translation of The Andria (Lancaster, 1987).

[1988 Hedley] Judith Hedley (ed.), An Edition of R.B.'s Appius and Virginia, Garland Publications in American and English Literature (New York, 1988).

[1989 Lyall] R.J. Lyall (ed.), Ane Satyre of the Thrie Estaitis, Canongate Classics (Edinburgh, 1989).

[1991 Axton \& Happé] Richard Axton and Peter Happé (eds), The Plays of John Heywood, Tudor Interludes (Cambridge, 1991).

[1992 Tydeman] William Tydeman (ed.), Two Tudor Tragedies, Penguin Classics (Harmondsworth, 1992).

[1992 White] Paul Whitfield White (ed.), Reformation Biblical Drama in England: An Old-Spelling Critical Edition, The Renaissance Imagination (New York, 1992).

[1993 Abrams] M. Howard Abrams (gen. ed.), The Norton Anthology of English Literature, 6th ed., 2 vols (New York, 1993).

[1993 Coldewey] John C. Coldewey (ed.), Early English Drama: An Anthology (New York, 1993).

[1995 Knittel \& Fattic] Frank Knittel and Grosvenor Fattic (eds), A Critical Edition of the Medieval Play Mankind (Lewiston, 1995).

[1996 Gildenhuys] Faith Gildenhuys (ed.), A Gathering of Griseldas: Three Sixteenth-Century Texts, Publications of the Barnabe Riche Society (Ottawa, 1996).

[1997 Knight \& Ohlgren] Stephen Knight and Thomas Ohlgren (eds), Robin Hood and Other Outlaw Tales, Middle English Texts Series (Kalamazoo, 1997).

[1997 Whitworth] Charles Walters Whitworth (ed.), Gammer Gurton's Needle, The New Mermaids, 2nd ed. (London, 1997).

[1998 Mace] Nigel Mace (ed.), The Three Estates (Aldershot, 1998). 
[1998 Riggio] Milla Cozart Riggio (ed.), The Play of Wisdom: Its Texts and Contexts, AMS Studies in the Middle Ages (New York, 1998).

[1999 Beecher] Donald Beecher (ed.), Supposes (I suppositi) (1509), Carleton Renaissance Plays in Translation (Ottawa, 1999).

[1999 Davidson \& Happé] Clifford Davidson and Peter Happé (eds), The Worlde and the Chylde, Early Drama, Art, and Music (Kalamazoo, 1999).

[2000 Abrams \& Greenblatt] M. Howard Abrams and Stephen Greenblatt (gen. eds), The Norton Anthology of English Literature, 7th ed., 2 vols (New York, 2000).

[2000 Walker] Greg Walker (ed.), Medieval Drama: An Anthology, Blackwell Anthologies (Malden, 2000).

[2001 King] Ros King (ed.), The Works of Richard Edwards: Politics, Poetry, and Performances in Sixteenth-Century England, The Revels Plays Companion Library (Manchester, 2001).

[2003 Wise \& Walker] Jennifer Wise and Craig S. Walker (eds), The Broadview Anthology of Drama, vol 1 (Peterborough, 2003).

[2005 Kinney] Arthur F. Kinney (ed.), Renaissance Drama: An Anthology of Plays and Entertainments, Blackwell Anthologies, 2nd ed. (Malden, 2005).

[2006 Black et al] Joseph Black, et al (gen. eds), The Broadview Anthology of British Literature, 2 vols (Peterborough, 2006).

[2006 Greenblatt] Stephen Greenblatt (gen. ed.), The Norton Anthology of English Literature, 8th ed., 2 vols (New York, 2006).

[2007 Davidson, Walsh \& Broos] Clifford Davidson, Martin W. Walsh, and Ton J. Broos (eds), Everyman and Its Dutch Original, Elckerlijc, Middle English Texts Series (Kalamazoo, 2007).

[2008 Ashley \& NeCastro] Kathleen M. Ashley and Gerard NeCastro (eds), Mankind, Middle English Texts Series (Kalamazoo, 2008).

[2008 Klausner] David N. Klausner (ed.), Two Moral Interludes: The Pride of Life and Wisdom, Middle English Texts Series (Kalamazoo, 2008).

[2009 Black et al] Joseph Black, et al (gen. eds), The Broadview Anthology of British Literature, 2nd ed., 2 vols (Peterborough, 2009). 
[2009 Bruster \& Rasmussen] Douglas Bruster and Eric Rasmussen (eds), Everyman and Mankind, Arden Early Modern Drama (London, 2009).

[2009 Gainor et al] J. Ellen Gainor, Stanton B. Garner, and H. Martin Puchner (eds), The Norton Anthology of Drama (New York, 2009).

[2012 Fitzgerald \& Sebastian] Christina Fitzgerald and John T. Sebastian (gen eds), The Broadview Anthology of Medieval Drama (Peterborough, 2012).

[2012 Greenblatt] Stephen Greenblatt (gen. ed.), The Norton Anthology of English Literature, 9th ed., 2 vols (New York, 2012).

[2013 Betteridge \& Walker] Thomas Betteridge and Greg Walker (eds), The Oxford Anthology of Tudor Drama (Oxford, 2013).

\section{Notes:}

I wish to thank Erin Kelly and Maura Giles-Watson for kindly inviting me to contribute, Greg Walker for sharing his table of contents, and the Australian Research Council for funding this research.

1 Andrew Lang, History of English Literature, from Beowulf to Swinburne, 2nd edn (New York, 1912), 158.

2 J.A. Symonds, Shakspere's Predecessors in the English Drama (London, 1884), 149.

3 Richard Allen Pacholski, 'The Humanist Drama of the Sir Thomas More Circle', $\mathrm{PhD}$ thesis (University of Wisconsin-Madison, 1969), 266.

4 Leah S. Marcus, 'Dramatic Experiments: Tudor Drama, 1490-1567', Arthur F. Kinney (ed.), Cambridge Companion to English Literature, 1500-1600 (Cambridge, 2000), 132, DOI: http://dx.doi.org/10.1017/CCOL0521582946.007.

5 Frederick S. Boas, An Introduction to Tudor Drama (Oxford, 1933), 1.

6 C.F. Tucker Brooke, The Tudor Drama: A History of English National Drama to the Retirement of Shakespeare (Boston, 1911), 103-4.

7 Norman Rabkin, 'Stumbling toward Tragedy', Peter Erickson and Coppélia Kahn (eds), Shakespeare's 'Rough Magic': Renaissance Essays in Honor of C.L. Barber (Newark, 1985), 28.

8 Brett D. Hirsch, 'The Kingdom has been Digitized: Electronic Editions of Renaissance Drama and the Long Shadows of Shakespeare and Print', Literature Compass 8.9 (2011), 568-91, DOI: http://dx.doi.org/10.1111/j.1741-4113.2011.00830.x. 
9 Ian Lancashire (ed.), Two Tudor Interludes: Youth and Hick Scorner, The Revels Plays (Manchester, 1980).

10 Paula Neuss (ed.), Magnificence, The Revels Plays (Manchester, 1980).

11 Ros King (ed.), The Works of Richard Edwards: Politics, Poetry, and Performances in Sixteenth-Century England, The Revels Plays Companion Library (Manchester, 2001).

12 Both Lancashire's and Neuss's volumes were printed exclusively in hardcover; King's volume was printed in hardcover in 2001 and in paperback in 2009.

13 G.A. Lester (ed.), Three Late Medieval Morality Plays, The New Mermaids (London, 1981); Charles Whitworth (ed.), Three Sixteenth Century Comedies, The New Mermaids (London, 1984); Douglas Bruster and Eric Rasmussen (eds), Everyman and Mankind, Arden Early Modern Drama (London, 2009).

14 Alexandra F. Johnston, 'Tudor Drama, Theatre and Society', Robert Tittler and Norman Jones (eds), A Companion to Tudor Britain (Malden, 2004), 431 (emphasis added), DOI: http://dx.doi.org/10.1002/9780470997109.ch25.

15 For full bibliographical details, see Appendix 1. These figures include the plays and fragments listed in Darryl Grantley, English Dramatic Interludes 13001580: A Reference Guide (Cambridge, 2003), DOI: http://dx.doi.org/10.1017 /CBO9780511483592. While Grantley distinguishes between critical editions and facsimiles in his lists of texts and editions, he conflates diplomatic transcriptions (such as those produced for the Malone Society Reprints) with old-spelling critical editions. Grantley's lists of editions are also admittedly incomplete and (by now) dated. The statistics offered in the present paper are those of the author, checked against Grantley and entries in his Bibliography of Editions of Early English Drama $(B E E E D)$ database. Although efforts to ensure the accuracy, currency and completeness of the data cited are made, the figures offered in this paper and its apparatus should be appreciated only as rough estimates for the purpose of comparison.

16 Peter Happé (ed.), The Complete Plays of John Bale, Tudor Interludes, 2 volumes (Cambridge, 1985-86); Richard Axton and Peter Happé (eds), The Plays of John Heywood, Tudor Interludes (Cambridge, 1991); and, Alan H. Nelson (ed.), The Plays of Henry Medwall, Tudor Interludes (Cambridge, 1980).

17 Christina M. Fitzgerald and John T. Sebastian (eds), The Broadview Anthology of Medieval Drama (Peterborough, 2012). The plays include Everyman, Fulgens and Lucres, Gammer Gurton's Needle, Like Will Unto Like, Mankind, Nice Wanton, The Play of the Sacrament (Croxton), The Play of the Weather, Wit and Science, and The Interlude of Youth.

18 The Oxford Anthology of Tudor Drama, under the editorship of Greg Walker and Thomas Betteridge, to be published in December 2013, will contain modern-spelling 
texts of the following eight early Tudor plays: The Play of the Sacrament (Croxton), Fulgens and Lucrece, Everyman, The Play of the Weather, Gammer Gurton's Needle, Damon and Pythias, Thyestes, and Cambyses. Broadview Press has also recently commissioned Alan Stewart to prepare an Anthology of Tudor Drama, the contents of which — like the format and pricing of both forthcoming volumes — are unknown at time of writing.

19 Greg Walker (ed.), Medieval Drama: An Anthology, Blackwell Anthologies (Malden, 2000).

20 'Medieval Drama: An Anthology', Wiley, Web, 2 Dec. 2011, http:/www.wiley.com /WileyCDA/WileyTitle/productCd-0631217274.html. The title is listed as in print on the publisher's United Kingdom and Australia/New Zealand catalogues, priced GBP £25.99, AUD \$52.95, and NZD \$59.99 respectively. Perhaps these are old stock.

21 'Tudor Interludes', Boydell \& Brewer, Web, 2 Dec. 2011, http://www.boydellandbrewer .com/store/listCategoriesAndProducts.asp?idCategory=250.

22 David Bevington (ed.), Medieval Drama (Indianapolis, 2012); see 'Medieval Drama', Hackett Publishing, Web, 11 Nov. 2012, http://www.hackettpublishing.com /medieval-drama-2728. It is a reprint of the Houghton Mifflin edition with an updated 'Suggestions for Further Reading'.

23 Eugene Giddens, How to Read a Shakespearean Playtext (Cambridge, 2011), 149.

24 Michael Leslie, 'Electronic Editions and the Hierarchy of Texts', Warren Chernaik, Caroline Davis, and Marilyn Deegan (eds), The Politics of the Electronic Text (Oxford, 1993), 50.

25 Gary Taylor, 'The Renaissance and the End of Editing', George Bornstein and Ralph G. Williams (eds), Palimpsest: Editorial Theory in the Humanities (Ann Arbor, 1993), 132.

26 Hirsch, 'The Kingdom has been Digitized', 573-7.

27 Giddens, How to Read a Shakespearean Playtext, 148.

28 This includes Internet Shakespeare Editions (1996-) under the coordinating editorship of Michael Best; Queen's Men Editions (2006-) under the general editorship of Helen Ostovich; Digital Renaissance Editions (2007-) under the coordinating editorship of the present author; and Richard Brome Online (2010-) under the general editorship of Richard Allen Cave.

29 Pacholski, 'The Humanist Drama', 266; see also Tucker Brooke, The Tudor Drama, $103-4$.

30 Cartwright, Theatre and Humanism: English Drama in the Sixteenth Century (Cambridge, 1999), 2, DOI: http://dx.doi.org/10.1017/CBO9780511483479. 
31 Ibid, 4. In particular, Cartwright refers to David Bevington, From Mankind to Marlowe: Growth and Structure in the Popular Drama of Tudor England (Cambridge, 1962) and Robert Weimann, Shakespeare and the Popular Tradition of the Theater: Studies in the Social Dimension of Dramatic Form and Function (Baltimore, 1978).

32 Cartwright, Theatre and Humanism, 6, 1, 8.

33 For a discussion of the York cycle in modern performance, see Margaret Rogerson, Playing a Part in History: The York Mysteries, 1951-2006 (Toronto, 2009).

34 For more on these groups and their performances, see Medieval Plays in Modern Performance (2MP). The 2MP project, a Worldwide Universities Network Initiative with partners in Bristol, Lancaster, Leeds, Southampton, Sydney, and Toronto, has been working since 2009 to document and catalogue archives of materials related to twentieth-century productions of early English drama; see http://www.bris.ac.uk /drama/2mp/.

35 Glynne Wickham (ed.), English Moral Interludes (London, 1976), v. A pertinent recent example is Staging the Henrician Court (2008-10), an interdisciplinary research project headed by Thomas Betteridge and Greg Walker, which included productions of The Play of the Weather and Magnificence in the Great Hall at Hampton Court Palace; see http://stagingthehenriciancourt.brookes.ac.uk/.

36 T.W. Craik, The Tudor Interlude: Stage, Costume, and Acting (London, 1958), 2.

37 Wickham, English Moral Interludes, v.

38 Scott McMillin and Sally-Beth MacLean, The Queen's Men and Their Plays (Cambridge, 1998), 148.

39 T.S. Eliot, 'Introduction', Seneca his Tenne Tragedies translated into English (London, 1927), vi.

40 For a discussion of the attractiveness of electronic editions to early English drama more broadly, see Hirsch, 'The Kingdom has been Digitized'.

41 Marcus, 'Dramatic Experiments', 136.

42 Ibid, 136-37.

43 Louise Rayment's electronic edition of Wit and Science for Digital Renaissance Editions will attend to the play's musical contexts and include audio recordings of its songs.

44 Two projects are currently developing scale three-dimensional models of historical and modern performance spaces for such uses: the Simulated Environment for Theatre (SET), developed by a research team led by Jennifer Roberts-Smith, Stéfan Sinclair, and Stan Ruecker; and, experiments with motion capture in virtual reconstructions of early modern theatres undertaken by Joanne Tompkins and Matthew Delbridge using Ortelia. There are plans to integrate SET into editions of texts for Internet Shakespeare Editions and other projects using the same publishing platform, 
such as Queen's Men Editions and Digital Renaissance Editions. For more information, see http://www.humviz.org/set/ and http://www.ortelia.com/.

45 Marcus, 'Dramatic Experiments', 141.

46 For other applications of animated text in electronic editions of early English drama, see Michael Best, 'Standing in Rich Place: Electrifying the Multiple-Text Edition or, Every Text is Multiple', College Literature, 36.1 (2009), 32-6, DOI: http://dx.doi .org/10.1353/lit.0.0034; see also the prototypes developed by Alan Galey as part of his Visualising Variation project: http://individual.utoronto.ca/alangaley /visualizingvariation/.

47 Craik, The Tudor Interlude, 2.

48 These include editions of George Chapman's An Humorous Day's Mirth (ed. Eleanor Lowe) and the anonymous Fair Em (eds Brett D. Hirsch and Kevin Quarmby).

49 New Custom (London, 1573; sтc 6150), ЕЕво, A2r.

50 Martin Mueller, 'Back to the Future, or, Wanted: A Decade of High-Tech Lower Criticism', paper presented at the Chicago Digital Humanities and Computer Science Colloquium, November 18, 2012.

51 Representative studies include Jonathan Hope, The Authorship of Shakespeare's Plays (Cambridge, 1994), DOI: http://dx.doi.org/10.1017/CBO9780511518942; Ulrich Busse, Linguistic Variation in the Shakespeare Corpus (Amsterdam, 2002); MacDonald P. Jackson, Defining Shakespeare: Pericles as Test Case (Oxford, 2003), DOI: http://dx.doi.org/ 10.1093/acprof:oso/9780199260508.001.0001; Hugh Craig and Arthur F. Kinney (eds), Shakespeare, Computers, and the Mystery of Authorship (Cambridge, 2009), DOI: http://dx.doi.org/10.1017/CBO9780511605437; Lene B. Petersen, Shakespeare's Errant Texts (Cambridge, 2010); and, Mireille Ravassat and Jonathan Culpeper (eds), Stylistics and Shakespeare's Language (London, 2011).

52 Important discussions and applications of such methods outside of early modern studies include Franco Moretti, Graphs, Maps, Trees: Abstract Models for a Literary History (London, 2005); Matthew Jockers, Macroanalysis: Digital Methods and Literary History (Urbana, 2013); and, Michaela Mahlberg, Corpus Stylistics and Dickens's Fiction (New York, 2013).

53 For reasons discussed in more detail elsewhere (see Hirsch, 'The Kingdom has been Digitized', 575-80), such as professional skepticism and devaluation of collaborative, editorial, and digital projects (particularly in the context of university tenure, promotion, and evaluation) in addition to a range of complex technological considerations, the production of electronic editions of non-canonical drama will be noticeably slow in appearing. A number of electronic editions of early Tudor plays are in preparation for Digital Renaissance Editions, however, including Cambyses (ed. Julia M. Garrett), The Conflict of Conscience (ed. Erin Kelly), Damon and Pythias (ed. 
Donald Jellerson), Virtuous and Godly Susanna (ed. Brittany V. Vis), and Wit and Science (ed. Louise Rayment). John D. Cox will edit a selection of moral interludes for Digital Renaissance Editions, and Ian Lancashire has kindly granted permission for the series to publish revised versions of his (now out-of-print) Revels editions of Hick Scorner and The Interlude of Youth. The series anticipates proposals for editions of The (Nature of the) Four Elements, Gentleness and Nobility, and Ralph Roister Doister in the near future. With these editions in the pipeline and other proposals expected, a reasonable collection of modern-spelling, critical editions of early Tudor plays should be available for teaching and research within the next five years. The project's coordinating editor welcomes edition proposals from interested Early Theatre readers.

54 Seneca, Hercules Furens, trans. Jasper Heywood (Oxford, 1561; sтC: 22223), ЕEво, I1r. 
